\title{
Pemberdayaan masyarakat melalui budidaya ikan dengan menggunakan pakan yang mengandung kunyit di Kelurahan Umban Sari Kecamatan Rumbai Pekanbaru
}

\author{
Morina Riauwaty*, Windarti, Henni Syawal, \& Isma Mulyani \\ Universitas Riau \\ * morinariauwaty@yahoo.co.id
}

\begin{abstract}
Abstrak. Kelurahan Umban Sari merupakan salah satu kelurahan yang terdapat di Kecaatan Rumbai yang memiliki potensi dalam budidaya ikan baik di kolam terpal dan di keramba. Tujuan dari penyuluhan ini adalah untuk memberdayakan masyarakat di Kelurahan Umban Sari Kecamatan Rumbai dalam membuat pakan ikan yang mengandung kunyit. Metode yang diterapkan adalah persiapan wadah, pembuatan produk, analisa proksimat, sosialisasi, monitoring dan evaluasi. Hasil yang diperoleh adalah kelompok petani ikan di Kelurahan Umban Sari dapat membuat pellet ikan yang mengandung kunyit dan menerapkan pelelt tersebut untuk pemeliharaan ikan patin dan ikan lele. Kelompok petani ikan juga dapat membuat pelet secara mandiri dengan tingkat keberhasilan marteri sebesar 85\% dari jumlah peserta yang hadir. Hasil monitoring dan evaluasi dari program ini menunjukkan bahwa kelompok masyarakat di Kelurahan Umban Sari akan mengembangkan teknik pembuatan pelet yang mengandung kunyit dan akan menggunakan pelets tersebut untuk keberlanjutan program dan untuk meningkatkan produksi ikan budidaya.
\end{abstract}

Kata kunci: pakan; kurkumin; umban sari; rumbai; pangasius

\begin{abstract}
Umban sari Village is one of Village in the Rumbai Sub Regency, Pekanbaru. This Village has a potential of fish culture in pont and in fish cages. The aim of this socialization is to understand the community empowering through fish culture using turmeric enriched pellets in Umban Sari Village, Rumbai Sub-Regency. The metode used are the preparation of the program, the manufacturer of the product, proximate analyses, socialization, monitoring and evaluation. The result shown that the sociaty's empowerment is fish farmer in Umban Sari Village has potential ability to make the turmeric enriched pellets.The result of monitoring and evaluation shown that the fish farmer in Umban Sari Village is commited to develop the turmeric enriched fish fed pellet processing as the effort of program sustainability.
\end{abstract}

Keywords: feed; curcumin; umban sari village; rumbai; pangasius

\footnotetext{
To cite this article: Riauwaty, M., Windarti, H. Syawal, \& I. Mulyani. 2019. Pemberdayaan masyarakat melalui budidaya ikan dengan menggunakan pakan yang mengandung kunyit di Kelurahan Umban Sari, Kecamatan Rumbai Pekanbaru. Unri Conference Series: Community Engagement 1: 658-662

https://doi.org/10.31258/unricsce.1.658-662
} 


\section{PENDAHULUAN}

Seiring dengan meningkatkanya jumlah penduduk dari waktu ke waktu, maka kebutuhan ikan terus mengalami peningkatan. Untuk memenuhi permintaan pasar akan ikan maka usaha budidaya ikan menjadi suatu usaha yang sangat diminati masyarakat. Hasil usaha budidaya ikan air tawar sekarang ini belum dapat mencukupi permintaan pasar karena belum berhasil dalam pembudidayaan yang baik.

Salah satu faktor yang mempengaruhi keberhasilan usaha budidaya adalah adanya serangan penyakit. Penyakit yang dapat menyerang ikan diantaranya adalah yang disebabkan oleh bakteri. alah satu penyakit menular yang dapat menimbulkan kerugian besar adalah penyakit MAS (Motile Aeromonas Septicemia) atau disebut dengan penyakit bercak merah ikan (Red Spot Disease) yang disebabkan oleh bakteri Aeromonas hydrophila (Riauwaty dan Windarti (2016).

Selama ini penanggulangan penyakit ikan pada akuakultur telah sering dilakukan dengan menggunakan berbagai antibiotika. Pada umumnya pembudidaya sering melakukan pemberian berbagai macam antibiotik seperti ampicillin, chloramphenicol, dantetracycline pada ikan. Penggunaan antibiotik secara terus menerus dan bila penggunaannya tidak tepat dapat menyebabkan bakteri patogen menjadi resisten, terjadi penimbunan residu obat-obatan di lingkungan perairan serta di dalam tubuh ikan yang dapat menimbulkan efek berbahaya bagi yang mengkonsumsinya (Lukistyowati dan Syawal, 2013).

Salah satu alternatif yang dapat digunakan untuk menggantikan antibiotika dengan memanfaatkan bahan alami seperti kunyit (Curcuma domestica). Berdasarkan hasil penelitian yang dilakukan oleh Hidayati (2002) secara in vitro, membuktikan bahwa senyawa aktif dalam rimpang kunyit mampu menghambat pertumbuhan jamur, virus, dan bakteri baik Gram positif maupun Gram negatif, karena kunyit mengandung berbagai senyawa diantaranya adalah kurkumin.

Pemanfaatan kunyit dalam pakan ikan belum pernah dilaporkan karena belum pernah diteliti. Menurut Riauwaty dan Windarti (2016) penggunaan kunyit dalam pakan ikan dengan konsentrasi $0,7 \mathrm{~g} / \mathrm{Kg}$ pakan mampu meningkatkan daya tahan tubuh ikan terhadap serangan penyakit bakterial dan dapat meningkatkan kelulushidupan ikan mencapai $100 \%$. Pakan merupakan unsur yang sangat penting dalam menunjang pertumbuhan dan kelangsungan hidup ikan. Dalam usaha budidaya ikan, ketersediaan pakan yang cukup dalam jumlah dan kualitas dapat mendukung produktivitas yang maksmimal (Lestari et al., 2013). Usaha budidaya ikan, faktor pakan meupakan komponen terbesar sekitar 60-70\% untuk budidaya pembesaran sehingga memerlukan pengelolaan yang efektif dan efisien dengan cara meningkatkan produksi dengan menggunakan pakan yang berkualitas baik, murah dan aman (Kusnadi, 2014, Darmansyah et al., 2016). Tingginya harga pakan juga menjadi kendala dalam usaha budidaya ikan sehingga masyarakat tidak dapat melanjutkan usaha tersebut (Hanif et al., 2014).

Pemberdayaan masyarakat merupakan suatu hal yang penting dilakukan untuk meningkatkan taraf hidup masyarakat menjadi lebih baik. Usaha pemberdayaan ini dilakukan sesuai dengan prosedur dan model pemberdayaan partisipasi dan salah satunya dengan kegiatan pembudidayaan ikan (Hudaidah et al., 2017). Adapun proses pemberdayaan masyarakat dilakukan bagi pembudidaya ikan di Kelurahan Umban Sari, Kecamatan Rumbai Pekanbaru. Kelurahan Umban Sari ini merupakan salah satu kelurahan yang terdapat di Kecamatan Rumbai dengan luas area 8,68 km2. Pada tahun 2017 tercatat jumlah penduduk di Kelurahan Umban Sari sebanyak 15.588 jiwa terdiri dari 8073 laki-laki dan 7515 perempuan dengan kepadatan 1796 jiwa/km2.

Di Kelurahan Umban Sari terdapat anak sungai yang diberi nama Sungai Umban Sari. Akan tetapi masyarakat belum memanfaatkan sungai ini untuk usaha budidaya ikan dengan sistim keramba jaring apung. Masalah yang dihadapi karena masyarakat petani ikan mengetahui cara budidaya ikan dalam keramba. Selain itu usaha budidaya ikan lele di kolam di kolam pekarangan mengalami kegagalan karena adanya serangan penyakit seperti bakteri dan jamur. Dalam hal ini pembudidaya ikan memerlukan informasi yang berhubungan dengan hal-hal teknis dalam kegiatan budidaya ikan dengan pemanfaatan tanaman alami sebagai bahan untuk dicampurkan dalam pakan ikan. Kendala yang dihadapi oleh masyarakat di Kelurahan Umban Sari karena minimnya pengetahuan masyarakat tentang budidaya ikan apalagi pengetahuan tentang penyakit ikan budidaya dan pertumbuhan ikan yang lambat. Berdasarkan uraian diatas, maka tim penyuluh dari Fakultas Perikanan dan Kelautan Universitas Riau tertarik untuk melakukan penyuluhan tentang "Pemberdayaan masyarakat melalui budidaya ikan dengan pembuatan pakan ikan yang mengandung kunyit di Kelurahan Umban Sari, Kecamatan Rumbai Pekanbaru". 


\section{METODE}

\section{Waktu dan tempat}

Penyuluhan ini telah dilaksanakan pada tanggal 17 Juni sampai 19 Juli di Kelurahan Umban Sari, Kecamatan Rumbai, Pekanbaru.

\section{Alat dan bahan}

Alat yang digunakan pada program ini adalah ember, nampan, Sprayer, pengaduk, saringan, timbangan dan plastik. Bahan yang dibutuhkan adalah pelet komersil, bubuk kunyit, akuades.

\section{Prosedur pembuatan pellet yang mengandung kunyit}

Prosedur pembuatan pelet yang mengandung kunyit adalah sebagai berikut: 1. Persiapan alat dan bahan, 2 . Persiapan pembuatan bubuk kunyit, 3. Mencampur bubuk kunyit dengan pakan komersil, 4. Mengeringkan pelet.

\section{Bentuk kegiatan}

Kegiatan ini secara keseluruhan terdiri dari 1. Pembuatan produk dan analisis proksimat pakan yang telah mengandung kunyit, 2 Pembuatan video tutorial, 3. Pembuatan buku Teknologi Tepat Guna tentang pembuatan pakan ikan yang mengandung kunyit, 4. Sosialisasi dan pelatihan pembuatan pakan, 5. Monitoring dan Evaluasi.

\section{Metode pegumpulan data dan analisa data}

Metoda yang digunakan dalam pengumpulan data adalah dengan menggunakan Pre test dan Post test terkait dengan materi pembuatan pakan yang mengandung kunyit, melakukan wawancara, diskusi dan lembar observasi. Data yang diperoleh dianalisis dengan metode deskriptif.

\section{HASIL DAN PEMBAHASAN}

Penyuluhan tentang pembuatan pakan ikan yang mengandung kunyit untuk meningkatkan produksi budidaya ikan dilakukan secara bertahap dan melibatkan petani ikan dan masyarakat yang tertarik dalam pembudidayaan ikan serta ibu-ibu PKK di Kelurahan Umban Sari, Kecamatan Rumbai Pekanbaru. Kegiatan ini dilakukan pada kelompok budidaya ikan di Kelurahan Umban Sari yang berjumlah 28 orang yang terdiri dari 21 orang laki-laki dan 7 orang perempuan. Kegiatan ini dilaksanakan di Aula Kantor Lurah Umban Sari, Kecamatan Rumbai dan dihadiri oleh Ibu Lurah dan perangkatnya.

Kegiatan pemberdayaan masyarakat ini diawali dengan melakukan survey ke lokasi untuk melihat keadaan dan permasalahan yang ada di Kelurahan ini. Dari hasil survey diketahui bahwa di Kelurahan ini terdapat sungai kecil yang berada RW 11 dan RT 3. Akan tetapi sungai yang ada ini belum dimanfaatkan untuk budidaya ikan. Hasil survey menunjukkan bahwa masalah yang dihadapi oleh petani ikan adalah karena kurangnya pengetahuan masyarakat tentang budidaya ikan dan tentang cara menaggulangi penyakit pada ikan. Selain itu masyarakat juga belum memiliki pengetahui yang cukup tentang manfaat kunyit yang dicampurkan dalam pakan ikan dan kurangnya pasokan benih unggul serta minimnya modal untuk usaha tersebut. Dari uraian diatas, maka dipilihlah topik tentang pembuatan pakan ikan yang mengandung kunyit untuk meningkatkan daya tahan tubuh ikan terhadap penyakit. Tahap selanjutnya dilakukan persiapan instrumen monitoring dan evaluasi berupa pre test dan post test. Lembar observasi keterampilan dan juga lembar observasi kegiatan diberikan kepada peserta dan dianalisis. Selanjutnya dilakukan diskusi bersama masyarakat dan aparat kelurahan untuk keberlanjutan program ini.

\section{Pembuatan Pelet yang mengandung kunyit}

Pembuatan pelet yang mengandung kunyit dalam skala kecil telah dilakukan di Laboratorium Parasit dan Penyakit Ikan, Fakultas Perikanan dan Kelautan Universitas Riau. Terlebih dahulu alat dan bahan disiapkan, kemudian dilakukan pembuatan pakan yang mengandung kunyit sesuai dengan prosedur yang telah ditetapkan. Pelet yang telah jadi ini akan diuji kadar proksimat yang meliputi kadar protein, lemak, gula reduksi, serat, dan mineral. Hasil produk pelet yang mengandung kunyit ini tertera pada Gambar 1. 


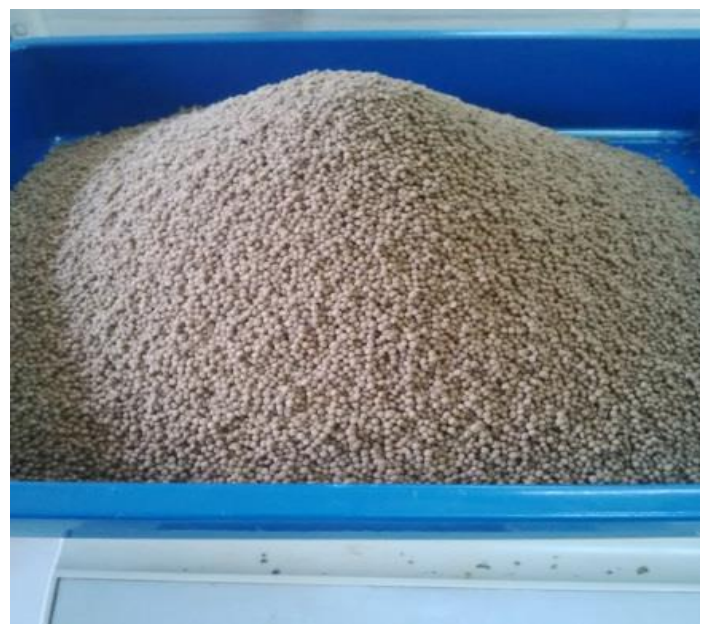

Gambar 1. Pelet yang mengandung kunyit

Hasil analisa kadar proksimat tehadap pelet yang mengandung kunyit diketahui kadar protein sebesar 30\%, lemak $6,4 \%$, gula reduksi $4,8 \%$, serat kasar $7 \%$ dan mineral 0,4\%. Dari hasil analisa proksimat ini diketahui bahwa pelet yang mengandung kunyit telah memenuhi kriteria dalam pembuatan pakan ikan. Hal ini sesuai dengan Yuhanna dan Yulistiana (2017) bahwa kadar protein yang baik untuk ikan berkisar 30-36\%. Selanjutnya Boer et al.,(2014) menyatakan bahwa kualitas pakan yang baik adalah mengandung komposisi protein, lemak, mineral dan vitamin. Menurut Heriansah dan Aspari (2016) pembuatan pakan dengan penambahan probiotik dapat meningkatkan kualiats pakan.

Kegiatan pembuatan pelet yang mengandung kunyit ini dilakukan di halaman kantor Kelurahan Umban Sari, Kecamatan Rumbai. Selama pelatihan kelompok petani ikan diberi pengetahua tentang keuntungan budidaya ikan di kolam terpal dan teknik budidaya ikan di keramba jaring apung. Selain itu diberikan juga materi tentang manfaat kunyit bagi kesehatan ikan, cara pembuatan pakan ikan yang berkualitas, teknik pemberian pakan pada ikan, pemanenan ikan dan pengukuran kualitas air.

Hasil evaluasi program pemberdayaan masyarakat dilakukan sebanyak dua kali yaitu evaluasi awal dan evaluasi akhir. Evaluasi awal dilakukan sebelum peserta mendapatkan materi penyuluhan. Evaluasi awal ini dilakukan untuk mengetahui tingkat pengetahuan para peseta sebelum mengikuti penyuluhan. Evaluasi akhir dilaksnakan pada akhir kegiatan penyuluhan, setelah peserta mengikuti semua materi penyuluhan. Evaluasi akhir dilakukan dengan memberikan pertanyaan yang sama dengan evaluasi awal, hal ini dilakukan untuk mengetahui tingkat pengetrahuan peserta dalam menyerab materi penyuluhan. Dan untuk mengetahui adanya peningkatan pengetahuan setelah dilakukan pelatihan. Hasil evaluasi awal dan akhir peserta penyuluhan dapat dilihat pada Tabel 1.

Tabel 1. Hasil evaluasi materi penyuluahn terhadap peserta pelatihan

\begin{tabular}{cllc}
\hline No & Pemahaman Materi & Evaluasi awal (\%) & Evaluasi akhir (\%) \\
\hline 1. & $\begin{array}{l}\text { Teknik budidaya ikan (kolam terpal dan } \\
\text { keramba) }\end{array}$ & 22,3 (rendah) & 87,7 (tinggi) \\
2. & $\begin{array}{l}\text { Penanggulangan penyakit ikan budidaya } \\
\text { 3. }\end{array}$ & 15,8 (rendah) & 90,5 (tinggi) \\
antibakteri & Pengukuran parameter kaulaitas air & 20,2 (rendah) & 93,7 (tinggi) \\
\hline
\end{tabular}

Hasil evaluasi akhir menunjukkan bahwa kegiatan ini memberikan pengaruh yang signifikan dimana dengan adanya penyuluhan ini pengetahuan dan pemahaman masyarakat meningkat. Sebelum dilakukan penyuluhan tingkat pengetahuan pembudidaya rata-rata $25,4 \%$ (rendah) dan setelah dilakukan penyuluhan terjadi peningkatan sebesar 90,3\% (tinggi). Menurut Nirmalasari et al., 2013 bahwa dengan penyuluhan dapat meningkatkan pengetahuan dan kreativitas masyarakat. Dengan demikian kegiatan ini dapat meningkatkan 
pengetahuan masyarakat dan meningkatkan keterampilan dalam pembuatan pakan ikan yang mengandung kunyit. Selain itu dengan meningkatnya pengetahuan masyarakat di Kelurahan Umban Sari diharapkan dapat meningkatkan kesejahteraan masyarakat. Dengan penyuluhan yang telah dilakukan diharapkan dapat berkelanjutan dan berkembang dengan baik untuk memenuhi kebutuhan masyarkat akan ikan.

\section{KESIMPULAN}

Masyarakat di Kelurahan Umban Sari Kecamatan Rumbai dapat membuat pakan ikan yang mengandung kunyit dan dapat menpraktekkan langsung sebagai solusi mahalnya harga pakan ikan di pasaran dan dapat meningkatkan daya tahan tubuh ikan terhadap serangan penyakit bakterial. Kelompok petani ikan di Kelurahan Umban Sari juga akan terus menggunakan pelet yang mengandung kunyit untuk keberlanjutan usaha budidaya ikan.

\section{UCAPAN TERIMAKASIH}

Penulis mengucapkan terimakasih kepada Ketua Lembaga Penelitian dan Pengabdian Kepada Masyarakat Universitas Riau yang telah mendanai kegiatan ini melalui Program Hibah Pengabdian tahun 2019.

\section{DAFTAR PUSTAKA}

Boer, I., Adelina, \& N. A. Pamukas. 2014. Pemanfaatan fermentasi Ampas tahu dalam pakan ikan untuk pertumbuhan Ikan gurami (Ospronemus gouramy) Dalam: Prosiding Seminar Antarbangsa ke 2, Ekologi, Habitat Manusia dan Perubahan Persekitaran. Riau (ID). Universitas Riau.

Darmansyah A, Sulistiono, Nugroho, Supriyono E. 2016. Pemberdayaan Masyarakat melalui Pengembangan Budidaya Ikan Lele di Desa Balongan, Indramayu, Jawa Barat. Agrokreatif. Jurnal Ilmiah Pengabdian Masyarakat, 2(1), 8-16.

Heriansah, \& Aspari, D.N.F. 2016. Pembuatan pakan dengan Bahan Baku Lokal, Penggunaan Probiotik dan Penerapan Manajemen Usaha Bagi Kelompok Pembudidaya Ikan di Kecamatan Citta Kabupaten Soppeng. Jurnal Balik Diwa, 2(7), 30-37.

Hudaidah., S. Wardiyanto, Hasani, \& Q. Yusuf, M.W. 2017. Pemberdayaan masyarakat melalui Pengembangan Budidaya Ikan lele Teknologi Bioflok di Kelurahan Pinang Jaya, Bandar Lampung, Lampung. Jurnal Pengabdian kepada Masyarakat, $6 \mathrm{hlm}$.

Hanif., Nurdin, \& Mawardi, I. 2014. Pengabdian Bagi Petani Ikan Bandeng Desa Jambo Timu Pemkot Lhokseumawe yang menghadapi Masalah Tingginya Harga Pakan. Prosiding Seminar Nasional Penelitian dan PKM Sains, Teknologi dan Kesehatan, 299-306 hlm.

Hidayati, E., Juli, N., \& Marwani, E. (2002). Isolasi Enterobacteriaceae Patogen dari Makanan Berbumbu dan Tidak Berbumbu Kunyit (Curcuma longa L.) Serta Uji Pengaruh Ekstrak Kunyit (Curcuma longa L.) Terhadap Pertumbuhan Bakteri yang Diisolasi. Bandung: Departemen Biologi, FPMIPA ITB. $54 \mathrm{hlm}$.

Kusnadi, H. 2014. Pelatihan Pembuatan Pakan Ikan lele, Mas dan Nila. Bengkulu (ID): Dinas Peternakan dan Perikanan Kabuaten Rejang Lebong.

Lestari, S. F., Yuniarti, S, \& Z. Abidin. 2013. Pengaruh Formulasi Pakan berbahan baku Tepung Ikan, Tepung jagung, Dedak Halus dan Ampas Tahu terhadap pertumbuhan Ikan nila (Oreochromis niloticus sp.). Jurnal Kelautan, 6 (1), 34-46.

Lukistyowati, I., \& H. Syawal. 2013. Potensi Pakan yang Mengandung Sambiloto (Andrographis paniculata) dan Daun Jambu Biji (Psidium guajava) untuk Menanggulangi Bakteri Aeromonas hydrophila pada Ikan Baung (Mystus nemurus). Jurnal Akuakultur Rawa Indonesia, 1(2), 135-147.

Nirmalasari, K.P, Risti, A.K, \& Juwanita. 2013. PROSIHTA Pelet ikan alternatif untuk meningkatkan Produktivitas Budidaya ikan lele di Desa Setono, Kecamatan Ngrambe Kabupaten Ngawi. Hasil kegiatan PKMM. Madiun (ID): IKIP PGRI Madiun.

Riauwaty, M., \& Windarti. 2016. Potensi ekstrak kunyit untuk menanggulangi penyakit MAS pada ikan patin (Pangasius hypopthalmus). Lembaga Penelitian Universitas Riau. Pekanbaru. $50 \mathrm{hlm}$.

Yuhanna, W. L., \&Yulistiana, Y. G. 2017. Pemberdayaan Masyarakat Desa Wakah, Kecamatan Ngrambe melalui Pembuatan Pakan Lele Alternatif dari Ampas Tahu dan Probiotik. Agrokreatif. J Ilmiah Pengabdian kepada Masyarakat, 3(2), 108-114. 